\title{
USIA MENARCHE, KONSUMSI PANGAN, DAN STATUS GIZI ANAK PEREMPUAN SEKOLAH DASAR DI BOGOR
}

\author{
(Age of Menarche, Food Consumption, and Nutritional Status of Female \\ Elementary School Children in Bogor)
}

\author{
Sanya Anda Lusiana ${ }^{1}$ dan Cesilia Meti Dwiriani²
}

\footnotetext{
${ }^{1}$ Alumni Program Studi Gizi Masyarakat dan Sumberdaya Keluarga, Fakultas Pertanian (FAPERTA) IPB

2 Staf Pengajar Departemen Gizi Masyarakat, Fakultas Ekologi Manusia (FEMA) IPB Telp: 0251-8628304/8621258; Fax: 0251-8625846/8622276
}

\begin{abstract}
ABST RACT
The general objective of this research was to analyze the correlation between nutritional status, food consumption, and first menstruation age (menarche) of female Elementary School children. The research was conducted using cross sectional study design from May to J une 2007 in 14 Elementary Schools in Bogor. Sample criteria was: 5 grade student consist of pre menarche and post menarche students. A total of 120 students was chosen by purposive sampling. Spearman Correlation Test shows that there was no correlation between menarche age of mother and menarche age of the sample. Post menarche sample had sufficient energy intake but low iron intake. About $86.7 \%$ post menarche sample and $68.3 \%$ pre menarche sample had normal nutritional status. Spearman Correlation Test shows that nutritional status (BMI/Age) has negative significant correlation to menarche age $(r=0.062 ; \mathrm{P} \varangle 0.05)$. It means that better nutritional status implied in earlier menarche age.
\end{abstract}

Keyword: Nutritional status, food consumption and age of menarche

\section{PENDAHULUAN}

\section{Latar belakang}

Peningkatan kualitas sumberdaya manusia erat kaitannya dengan pangan dan gizi. Salah satu upaya untuk meningkatkan kualitas sumberdaya manusia ditujukan pada anak usia Sekolah Dasar (SD) karena mereka berada pada masa pertumbuhan yang sangat cepat dengan kegi- atan fisik yang sangat aktif. Pertumbuhan fisik pada anak usia ini merupakan hasil dari faktor lingkungan dan genetik serta interaksi keduanya. Pada penduduk miskin, faktor utama yang mempengaruhi pertumbuhan fisik anak usia sekolah adalah faktor lingkungan (pola konsumsi pangan, angka kesakitan, keterbatasan sanitasi, serta praktek higiene dan kesehatan yang buruk) yang dialami sebelum pubertas (Riyadi, 2003).

Pubertas adalah periode dalam rentang perkembangan ketika anak-anak berubah dari makhluk aseksual menjadi makhluk seksual yang dimulai antara usia 8.5 dan 11.5 tahun, dengan puncak rata-rata usia 12.5 tahun. Kriteria yang paling sering digunakan untuk menentukan timbulnya pubertas adalah menstruasi pada anak perempuan dan mimpi basah pada anak laki-laki (Hurlock, 1980). Ciri kelamin sekunder yang dialami anak perempuan adalah terjadi pertumbuhan payudara, tumbuh bulu yang halus berwarna gelap di tangan dan kakinya, mencapai pertumbuhan ketinggian badan yang maksimal setiap tahunnya, dan bulu kemaluan menjadi keriting (Fatimah, 2006).

Menstruasi merupakan ciri khas kematangan biologis seorang wanita yang secara fisik ditandai dengan keluarnya darah dari vagina dan merupakan salah satu perubahan yang terjadi pada alat reproduksi sebagai persiapan untuk kehamilan (Affandi \& Danukusumo, 1999). Panjang siklus menstruasi dipengaruhi oleh usia seseorang dan dukungan gizi. Kekurangan gizi akan menurunkan tingkat kesuburan. Asupan zat gizi yang baik diperlukan agar nantinya didapatkan keadaan sistem reproduksi yang sehat (Hanafiah, 1987).

Status gizi perlu diperhatikan karena status gizi yang kurang dapat mengakibatkan menstruasi lebih lambat dari yang seharusnya. Hal ini dikemukakan oleh Riyadi (2003) yaitu remaja putri yang bergizi baik mempunyai kecepatan pertumbuhan yang lebih tinggi pada masa sebelum pubertas (prapubertas) dibandingkan dengan remaja yang kurang gizi. Remaja kurang gizi tumbuh lebih lambat untuk waktu yang lebih lama, karena itu menarche (umur pertama kali mendapat menstruasi) juga tertunda. Berdasarkan hal tersebut, peneliti 
merasa tertarik untuk meneliti hubungan antara status gizi dan konsumsi pangan terhadap usia pertama kali menstruasi (menarche) anak perempuan usia sekolah dasar di Bogor.

\section{$\underline{\text { Tujuan }}$}

Tujuan penelitian ini adalah menganalisis hubungan status gizi dan konsumsi pangan dengan usia pertama kali menstruasi (menarche) pada anak usia sekolah dasar.

\section{METODE PENELITIAN}

\section{Desain, Tempat dan Waktu Penelitian}

Penelitian ini menggunakan desain crosssectional study. Data dikumpulkan untuk membandingkan status gizi dan konsumsi pangan dengan usia menarche anak perempuan sekolah dasar di Bogor. Penelitian ini dilakukan di 14 sekolah dasar di Bogor (SD Budi Mulia, SD Bina Insani, SD Ummul Quro, SDN Sindang Barang 1, SDN Sindang Barang 2, SDN Sindang Barang 3, SDN Sindang Barang 4, SDN Bubulak 1, SDN Loji 1, SDN Purbasari 3, SDN Cibalagung 5, SDN Gunung Batu 1, SDN Gunung Batu 2, dan SDN Situgede 3).

Pemilihan sekolah dilakukan secara sengaja yaitu sekolah dengan tingkat sosial ekonomi orang tua menengah ke atas dan menengah ke bawah juga berdasarkan pertimbangan kemudahan dalam melakukan penelitian serta keterbatasan waktu penelitian karena bertepatan dengan pelaksanaan ujian anak sekolah dasar yang dilaksanakan pada bulan Juni. Penelitian berlangsung selama dua bulan, yaitu bulan Mei 2007 sampai bulan Juni 2007.

\section{\umlah dan Cara Pengambilan Contoh}

Contoh penelitian adalah anak perempuan yang masih duduk di kelas lima Sekolah Dasar (SD). Pemilihan ini dilakukan karena usia pertama kali menstruasi (menarche) pada anak SD terjadi pada anak kelas lima, sehingga contoh yang diambil berasal dari kelas lima. Pemilihan contoh secara sengaja. Secara keseluruhan jumlah contoh sebanyak 120 yaitu 60 anak yang sudah menstruasi dan 60 anak yang belum menstruasi. Jumlah contoh dari setiap sekolah berbeda berdasarkan jumlah contoh yang sudah menstruasi di sekolah tersebut.

\section{Jenis dan Cara Pengumpulan Data}

Jenis data yang dikumpulkan meliputi data karakteristik contoh (umur, pengetahuan gizi dan hal-hal tentang menstruasi), usia menarche ibu, pola konsumsi pangan, konsumsi pangan dan status gizi.

\section{Pengolahan dan Analisis Data}

Data yang telah terkumpul diolah dan dianalisis secara deskriptif dan inferensia dengan menggunakan Microsoft Excel serta SPSS 13.0 for Windows. Bahan makanan dikelompokkan menjadi 7 kelompok (pangan pokok, protein hewani, protein nabati, sayuran, buah, jajanan dan minuman). Data konsumsi pangan yang dikumpulkan dikonversikan dalam bentuk energi, protein, Fe, vitamin A dan vitamin C menggunakan Daftar Komposisi Bahan Makanan (DKBM, 2004). Untuk menentukan Angka Kecukupan Gizi (AKG) vitamin dan mineral digunakan daftar pada AKG 2004 sedangkan AKG energi dan protein contoh ditentukan dengan rumus berikut:

$$
A K G=\frac{\text { BB contoh }}{\text { BB standar }} \times \text { AKG } 2004
$$

Selanjutnya, tingkat kecukupan energi dan protein diperoleh dengan rumus sebagai berikut:

$$
\text { Tingkat Kecukupan Gizi }=\frac{\text { Konsumsi }}{\text { AKG }} \times 100 \%
$$

Pengukuran status gizi dilakukan dengan metode antropometri melalui perhitungan indeks IMT/U. IMT/U digunakan untuk anak yang berumur 9-24 tahun, dengan menggunakan persentil. Untuk menilai kurus < persentil ke5 , normal persentil ke-5 $<x<$ persentil ke-85 dan gemuk $\geq$ persentil ke-85. Caranya adalah ditentukan dulu umur anak, kemudian IMT-nya dihitung berdasarkan rumus:

$$
\text { IMT }=\frac{\text { Berat Badan }(\mathrm{Kg})}{\text { Tinggi Badan }(\mathrm{m})^{2}}
$$

Hasil perhitungan tersebut dibandingkan dengan referensi pada umur yang sama dengan anak yang dinilai status gizinya.

Uji statistik yang digunakan yaitu: 1) Tabulasi frekuensi dan tabulasi silang untuk menganalisis karakteristik contoh (umur, pengetahuan gizi dan hal-hal tentang menstruasi), usia menarche ibu dan pola konsumsi pangan pada contoh yang sudah menstruasi dan belum menstruasi; 2) Uji beda Mann Whitney untuk menganalisis perbedaan status gizi dan $u j i$ beda $t$ untuk menganalisis perbedaan konsumsi pangan contoh yang sudah menstruasi dan belum menstruasi; 3) Uji korelasi Spearman untuk menganalisis hubungan status gizi dengan usia menarche, konsumsi pangan de- 
ngan usia menarche, usia menarche ibu dengan usia menarche contoh dan pengetahuan gizi dengan usia menarche.

\section{HASIL DAN PEMBAHASAN}

\section{Karakteristik Contoh}

Persentase jumlah contoh yang sudah menstruasi berbeda-beda antar sekolah (Tabel 2). Pada sekolah swasta dibutuhkan tiga sekolah untuk mendapatkan contoh sudah menstruasi (30 orang) sedangkan pada sekolah negeri dibutuhkan sebelas sekolah untuk mendapatkan contoh sudah menstruasi (30 orang).

\section{Umur}

Contoh dalam penelitian ini berumur 1012 tahun dan presentase terbesar pada umur 11 tahun, baik pada kelompok menstruasi maupun belum menstruasi (Tabel 1). Anak Sekolah Dasar (SD) disebut juga usia pertengahan anak-anak (middle childhood). Masa ini merupakan periode penting dalam kehidupan anak-anak. Pada usia ini anak memiliki fisik yang lebih tinggi dan kurus dibandingkan pada masa prasekolahnya (Papalia \& Olds, 1979).

Tabel 1. Sebaran Contoh berdasarkan Umur

\begin{tabular}{|c|c|c|c|c|c|c|}
\hline \multirow{2}{*}{ Variabel } & \multicolumn{2}{|c|}{ Menstruasi } & \multicolumn{2}{|c|}{$\begin{array}{c}\text { Belum } \\
\text { Menstruasi }\end{array}$} & \multicolumn{2}{|c|}{ J umlah } \\
\hline & $n$ & $\%$ & $\mathbf{n}$ & $\%$ & $\mathbf{n}$ & $\%$ \\
\hline \multicolumn{7}{|l|}{ Umur (th) } \\
\hline - 10 & 3 & 5.0 & 7 & 11.7 & 10 & 8.3 \\
\hline - 11 & 40 & 66.7 & 46 & 76.6 & 86 & 71.7 \\
\hline - 12 & 17 & 28.3 & 7 & 11.7 & 24 & 20.0 \\
\hline
\end{tabular}

\section{Tingkat Pengetahuan Gizi}

Pengetahuan gizi adalah pemahaman seseorang tentang ilmu gizi, zat gizi, serta interaksi antara zat gizi terhadap status gizi dan kesehatan (Suhardjo, 1996). Tingkat pengetahuan gizi diukur dari pertanyaan-pertanyaan umum mengenai gizi 15 pertanyaan, zat besi 5 pertanyaan dan menstruasi 7 pertanyaan. Pertanyaan gizi yang tidak dapat dijawab oleh contoh yaitu mengenai karbohidrat dan lemak (47.5\%), kekurangan vitamin dalam tubuh (51.7\%), dampak kurang gizi bagi anak (65.0\%) dan protein nabati $(66,7 \%)$. Pertanyaan-pertanyaan ini belum dapat dijawab oleh seluruh contoh diduga karena contoh sudah lupa mengenai pelajaran tersebut, selain itu contoh masih belum memahaminya (Tabel 3).

Pertanyaan mengenai zat besi yang dapat dijawab oleh sebagian besar contoh adalah mengenai tanda-tanda anemia. Pertanyaan yang tidak dapat dijawab oleh contoh yaitu mengenai fungsi zat besi, sumber zat besi, kekurangan zat besi dan golongan yang lebih mudah terkena anemia.

Pertanyaan mengenai menstruasi yang tidak dapat dijawab oleh sebagian besar contoh adalah mengenai perubahan yang paling terlihat ketika puber. Contoh masih belum memahami mengenai perubahan fisik, mental, moral dan spiritual. Contoh lebih mengetahui bahwa ketika menstruasi yang terjadi adalah payudara berkembang, tumbuh bulu-bulu halus dan sebagainya, namun belum mengerti apakah hal tersebut termasuk ke dalam perubahan fisik atau bukan (Tabel 3).

Tabel 2. Persentase Jumlah Contoh Menstruasi menurut Jumlah Siswi Kelas V

\begin{tabular}{clccr}
\hline No & \multicolumn{1}{c}{ Nama SD } & $\begin{array}{c}\text { J umlah Siswi Kelas V } \\
\text { (orang) }\end{array}$ & $\begin{array}{c}\text { J umlah Contoh } \\
\text { Menstruasi (orang) }\end{array}$ & $\%$ \\
\hline 1 & Budi Mulia & 68 & 10 & 14.7 \\
2 & Bina Insani & 59 & 10 & 16.9 \\
3 & Ummul Quro & 73 & 10 & 13.7 \\
4 & Sindang Barang 1 & 31 & 2 & 6.5 \\
5 & Sindang Barang 2 & 21 & 2 & 9.5 \\
6 & Sindang Barang 3 & 23 & 1 & 4.3 \\
7 & Sindang Barang 4 & 12 & 2 & 16.7 \\
8 & Bubulak 1 & 25 & 4 & 16.0 \\
9 & Loji 1 & 26 & 1 & 3.8 \\
10 & Purbasari 3 & 16 & 1 & 6.25 \\
11 & Cibalagung 5 & 23 & 3 & 13.0 \\
12 & Gunung Batu 1 & 41 & 8 & 19.5 \\
13 & Gunung Batu 2 & 60 & 2 & 3.3 \\
14 & Situgede 3 & 29 & 5 & 17.2 \\
\hline
\end{tabular}


Tabel 4. Sebaran Contoh berdasarkan Jawaban Benar terhadap Pertanyaan Pengetahuan Gizi

\begin{tabular}{|c|c|c|}
\hline \multirow{2}{*}{ Pertanyaan } & \multicolumn{2}{|c|}{ J awaban Benar } \\
\hline & $\mathbf{n}$ & $\%$ \\
\hline \multicolumn{3}{|l|}{ I. Pengetahuan Gizi } \\
\hline Makanan sehat adalah makanan yang cukup mengandung zat gizi dan higienis & 118 & 98.3 \\
\hline Zat gizi yang dibutuhkan tubuh karbohidrat, lemak, protein, vitamin dan mineral & 99 & 82.5 \\
\hline Makanan yang mengandung karbohidrat adalah beras & 98 & 81.7 \\
\hline Berdasarkan sumbernya lemak ada dua macam, yaitu lemak nabati dan hewani & 105 & 87.5 \\
\hline Karbohidrat dan lemak disebut sebagai zat tenaga & 57 & 47.5 \\
\hline Protein nabati terdapat dalam tempe & 80 & 66.7 \\
\hline Bahan pangan yang banyak mengandung air adalah ketimun & 102 & 85.0 \\
\hline Dampak kurang gizi bagi anak, kecuali pertumbuhan normal & 78 & 65.0 \\
\hline Agar tidak kekurangan gizi sebaiknya makan 4 sehat 5 sempurna & 118 & 98.3 \\
\hline Akibat utama kekurangan sumber energi adalah pertumbuhan badan terganggu & 112 & 93.3 \\
\hline Kekurangan vitamin dalam tubuh disebut avitaminosis & 62 & 51.7 \\
\hline Vitamin A banyak terdapat pada wortel & 114 & 95.0 \\
\hline Kekurangan vitamin A dapat meyebabkan rabun senja & 99 & 82.5 \\
\hline Vitamin $\mathrm{C}$ banyak terdapat pada jeruk & 113 & 94.2 \\
\hline Kekurangan vitamin $\mathrm{C}$ dapat menyebabkan penyakit sariawan & 102 & 85.0 \\
\hline \multicolumn{3}{|l|}{ II. Pengetahuan umum mengenai zat besi (Fe) } \\
\hline Fungsi zat besi adalah sebagai zat penambah darah & 42 & 35.0 \\
\hline Bahan makanan sumber zat besi adalah daging dan telur & 42 & 35.0 \\
\hline Kekurangan zat besi dapat mengakibatkan anemia & 51 & 42.5 \\
\hline Tanda-tanda anemia adalah lemah, letih, lesu & 107 & 89.2 \\
\hline Golongan yang lebih mudah terkena anemia adalah perempuan & 47 & 39.2 \\
\hline \multicolumn{3}{|l|}{ Ill.Pengetahuan umum mengenai menstruasi } \\
\hline Menstruasi adalah keluarnya darah setiap bulan & 117 & 97.5 \\
\hline Puber adalah bertambah dewasa (usia kedewasaan) & 112 & 93.3 \\
\hline Perubahan puber yang paling terlihat adalah perubahan fisik & 68 & 56.7 \\
\hline Tanda-tanda puber pada perempuan kecuali suara membesar & 77 & 64.2 \\
\hline Tanda-tanda menstruasi kecuali sakit gigi & 91 & 75.3 \\
\hline Pada umumnya menstruasi berlangsung selama 7 hari & 102 & 85.0 \\
\hline Jika sudah menstruasi dan tidak berhati-hati berteman maka dapat hamil & 113 & 94.2 \\
\hline
\end{tabular}

Lebih dari setengah contoh yang sudah menstruasi maupun belum menstruasi (58.3\%) memiliki pengetahuan gizi pada kategori sedang. Contoh yang memiliki tingkat pengetahuan kategori baik (tinggi) masing-masing $36.7 \%$ sudah menstruasi dan $26.7 \%$ belum menstruasi. Ini menunjukkan bahwa rata-rata tingkat pengetahuan gizi cukup baik (Tabel 4).

Tabel 4. Sebaran Contoh berdasarkan Tingkat Pengetahuan Gizi

\begin{tabular}{lcccc}
\hline \multirow{2}{*}{$\begin{array}{c}\text { Tingkat } \\
\text { Pengetahuan Gizi }\end{array}$} & \multicolumn{3}{c}{ Menstruasi } & \multicolumn{3}{c}{$\begin{array}{c}\text { Belum } \\
\text { Menstruasi }\end{array}$} \\
\cline { 2 - 5 } & $\mathbf{n}$ & $\%$ & $\mathbf{n}$ & $\%$ \\
\hline Rendah (<60\%) & 3 & 5.0 & 9 & 15.0 \\
Sedang (60\%-80\%) & 35 & 58.3 & 35 & 58.3 \\
Tinggi (> 80\%) & 22 & 36.7 & 16 & 26.7 \\
\hline
\end{tabular}

Sumber informasi contoh mengenai menstruasi umumnya berasal dari orang tua, khususnya ibu. Hal ini diduga karena adanya keterbukaan antara anak dan orang tua sehingga anak merasa jika ada sesuatu yang belum dipahami, maka anak bertanya kepada orang tuanya (Tabel 5).

Tabel 5. Sebaran Contoh berdasarkan Sumber Informasi Tentang Menstruasi

\begin{tabular}{lcccc}
\hline \multirow{2}{*}{$\begin{array}{c}\text { Sumber } \\
\text { Informasi }\end{array}$} & \multicolumn{2}{c}{ Menstruasi } & \multicolumn{2}{c}{$\begin{array}{c}\text { Belum } \\
\text { Menstruasi }\end{array}$} \\
\cline { 2 - 5 } & $\mathbf{n}$ & $\%$ & $\mathbf{n}$ & $\%$ \\
\hline Orang tua & 41 & 68.3 & 43 & 71.6 \\
Kakak & 10 & 16.7 & 9 & 15.0 \\
Teman & 3 & 5.0 & 7 & 11.7 \\
Lainnya & 6 & 10.0 & 1 & 1.7 \\
\hline
\end{tabular}

Rata-rata umur menarche contoh adalah 10.3 tahun. Sebagian besar contoh (86.7\%) mengalami menarche pada umur 10-11 tahun. Sebesar 13.3\% contoh mendapat menstruasi pada umur $<10$ tahun (Tabel 6). Riyadi (2003) menyatakan bahwa menstruasi yang dimulai antara umur 10 dan 16 tahun dipengaruhi oleh beberapa faktor, yaitu kesehatan wanita, keturunan, konsumsi gizi dan status gizi.

Penurunan usia awal menstruasi disebabkan peningkatan standar kehidupan ekonomi dan kemudahan akses perawatan kesehatan. 
Hal ini dibuktikan dengan penelitian yang dilakukan oleh Utami (2003) bahwa siswi-siswi di SMUN 1 Bogor $(34,4 \%)$ dan SMUN 81 Jakarta (35.8\%) mengalami menstruasi pertama pada umur 12 tahun sedangkan pada siswi SMUN 1 Ciampea mengalami menstruasi pertama kali pada umur 13 tahun (51.0\%). Lokasi SMUN 1 Bogor dan SMUN 81 Jakarta berada di kota Bogor dan Jakarta sehingga lebih mudah mendapatkan akses perawatan kesehatan serta memiliki status sosial ekonomi yang lebih baik dibandingkan SMUN 1 Ciampea.

Sebesar $76.7 \%$ contoh mengatakan memberitahukan orang tua khususnya ibu ketika pertama kali menstruasi. Hal ini diduga karena contoh menganggap orang yang paling dekat dan paling dipercayainya adalah orang tua khususnya ibu (Tabel 6).

Sebesar $58.3 \%$ contoh menjawab tidak selalu mendapat menstruasi setiap bulannya. Hal ini dipengaruhi karena contoh baru mengalami menstruasi sehingga tubuh membutuhkan waktu untuk membiarkan segala perubahan terjadi (Affandi \& Danukusumo, 1990). Sebagian besar contoh (88.3\%) menjawab lama menstruasinya 4-7 hari setiap bulannya. Ratarata lama menstruasi antara 3-5 hari dianggap normal dan lebih dari 8 atau 9 hari dianggap tidak normal. Perbedaan lama menstruasi merupakan proses fisiologik yang dipengaruhi banyak faktor antara lain lingkungan, lamanya menstruasi ibu, usia dan ovulasi.

Sebesar $66.7 \%$ contoh mengalami siklus menstruasi selama 25-35 hari. Panjang siklus menstruasi normal adalah 28 hari. Rata-rata panjang siklus haid pada gadis usia 12 tahun yaitu 35 hari dan dapat dipengaruhi oleh usia seseorang. Selain itu faktor lain yang mengganggu kelancaran siklus menstruasi adalah stres, perubahan berat badan, olahraga yang berlebihan dan keluhan menstruasi. Pada siklus wanita, hormon selalu berubah naik turun yang dapat mempengaruhi wanita baik secara mental maupun fisik (Hanafiah, 1987) (Tabel 8). Sebagian besar contoh (88.3\%) menjawab $\leq$ 14 kali mendapat menstruasi sampai wawancara dilakukan. Pada saat wawancara dilakukan, terdapat 6 orang contoh yang baru mendapat menstruasi pertama kalinya (Tabel 6).

Hampir seluruh contoh (90\%) menjawab memiliki keluhan ketika mengalami menstruasi. Ratsmawan (2007) menyatakan PMS (Pre Menstrual Syndrome) diderita perempuan yang mengalami ketidakseimbangan hormon, misalnya atlet, penderita obesitas, pemakai narkoba dan pecandu alkohol. Atlet biasanya tidak menyimpan banyak lemak tubuh, padahal lemak adalah penghasil hormon estrogen akibatnya tubuh mengalami kekurangan estrogen. Selain gangguan metabolisme, pola nutrisi yang tidak seimbang berupa diet tinggi lemak, tinggi garam dan gula, rendah vitamin dan mineral, sedikit serat dapat menimbulkan PMS. Konsumsi kafein serta alkohol yang berlebihan dapat memperberat gejala yang ada. Berdasarkan hasil dari beberapa penelitian yang telah dilakukan telah diketahui bahwa prevalensi dismenore (keluhan akibat rasa sakit saat menstruasi) yaitu sebesar 3-90\%.

Berbagai laporan memberitahukan bahwa prevalensi PMS sebesar 5-95\% dari wanita yang telah menstruasi (Jones \& Jones, 1982 dalam Utami, 2003).

Pada Tabel 6 dapat diketahui bahwa keluhan yang biasa dirasakan oleh lebih dari setengah contoh (55.6\%) adalah sakit/kram di bawah perut. Keluhan menstruasi ini bersifat subyektif, sehingga berat atau intensitasnya sukar dinilai. Oleh karena hampir semua wanita mengalami keluhan sakit atau kram di bawah perut menjelang dan saat menstruasi disertai rasa mual maka sering memaksa penderita untuk beristirahat dan meninggalkan aktivitasnya selama beberapa jam atau beberapa hari (Simanjuntak, 1987).

Penelitian Khaerunnisa (2005) mengungkapkan bahwa hampir seluruh contoh (93.9\%) mahasiswi TPB mengeluhkan sakit/kram di bawah perut pada saat menstruasi. Ratsmawan (2007) menyatakan bahwa sakit/kram di bawah perut disebabkan oleh otot tertentu mengejang, sementara darah dan pelapis rahim terdorong ke luar. Beberapa perempuan merasa tubuhnya menggemuk menjelang menstruasi. Kenaikan berat badan disebabkan adanya retensi cairan yang bertambah bahkan berlebihan dalam tubuh menjelang menstruasi. Selain itu, ketika menstruasi beberapa wanita nafsu makannya cenderung bertambah dan lebih menyukai makanan yang manis seperti coklat. Rata-rata angka kejadian sakit/ kram menstruasi di dunia sangat besar yaitu lebih dari 50\%. Di Amerika, persentase sakit/ kram menstruasi sekitar 60\%, Swedia 72\% dan di Indonesia 55\% wanita tersiksa sakit/kram selama menstruasi bahkan tidak mampu beraktivitas (Lie, 2004 dalam Khaerunnisa, 2005).

Sebagian besar contoh (86.7\%) menjawab tidak meminum jamu/kiranti untuk menghilangkan/meredakan keluhan yang biasanya dirasakan ketika menstruasi. Upaya paling efektif yang dilakukan oleh contoh untuk mengurangi rasa sakitnya adalah dengan beristirahat dan berbaring atau juga mengompres 
perut dengan air panas. Pengompresan dengan air panas pada perut bagian bawah dapat mengurangi penderitaan akibat nyeri yang hebat (Simanjuntak, 1987).

Perasaan yang dialami contoh ketika pertama kali mendapat menstruasi adalah ta- kut (41.7\%), biasa saja (23\%), malu (9\%) dan risih/jijik (3\%). Perasaan yang muncul adalah normal karena ketika pertama kali menstruasi yang dirasakan adalah takut karena ketidaktahuan tentang hal tersebut.

\begin{tabular}{|c|c|c|}
\hline Variabel & $\mathbf{n}$ & $\%$ \\
\hline \multicolumn{3}{|l|}{ 1. Usia pertama kali menstruasi } \\
\hline - 9 tahun & 8 & 13.3 \\
\hline - 10-11 tahun & 52 & 86.7 \\
\hline \multicolumn{3}{|c|}{ 2. Pertama kali memberitahukan mendapat menstruasi } \\
\hline - orang tua & 46 & 76.7 \\
\hline - kakak & 9 & 15.0 \\
\hline - teman & 3 & 5.0 \\
\hline - lainnya (bibi, nenek) & 2 & 3.3 \\
\hline \multicolumn{3}{|l|}{ 3. Keteraturan menstruasi } \\
\hline - tidak teratur & 35 & 58.3 \\
\hline - teratur & 25 & 41.7 \\
\hline \multicolumn{3}{|l|}{ 4. Lama menstruasi } \\
\hline - $<4$ hari & 5 & 8.3 \\
\hline - 4-7 hari & 53 & 88.3 \\
\hline - $\quad>7$ hari & 2 & 3.4 \\
\hline \multicolumn{3}{|l|}{ 5. Siklus menstruasi } \\
\hline - $\quad<25$ hari & 14 & 23.3 \\
\hline - 25-35 hari & 40 & 66.7 \\
\hline - $\quad>35$ hari & 6 & 10.0 \\
\hline \multicolumn{3}{|l|}{ 6.Frekuensi menstruasi hingga sekarang } \\
\hline - $0-14$ kali & 53 & 88.3 \\
\hline - $\quad>14$ kali & 7 & 11.7 \\
\hline \multicolumn{3}{|l|}{ 7. Adanya keluhan selama menstruasi } \\
\hline - tidak & 6 & 10.0 \\
\hline - ya & 54 & 90.0 \\
\hline \multicolumn{3}{|l|}{ 8. Keluhan yang biasa dirasakan } \\
\hline - sakit kepala & 5 & 9.3 \\
\hline - jerawat & 12 & 22.2 \\
\hline - sakit/keram di bawah perut & 30 & 55.6 \\
\hline - lesu & 7 & 12.9 \\
\hline \multicolumn{3}{|l|}{ 9. Kebiasaan meminum suplemen/jamu } \\
\hline - tidak & 52 & 86.7 \\
\hline - ya (kiranti) & 8 & 13.3 \\
\hline \multicolumn{3}{|c|}{ 10. Perasaan ketika pertama kali menstruasi } \\
\hline - malu & 9 & 15.0 \\
\hline - $r i s i h / j i j i k$ & 3 & 5.0 \\
\hline - takut & 25 & 41.7 \\
\hline - biasa saja & 23 & 38.3 \\
\hline \multicolumn{3}{|c|}{ 11. Makanan pantangan selama menstruasi } \\
\hline - tidak ada & 19 & 31.7 \\
\hline - ikan & 4 & 6.7 \\
\hline - nenas & 26 & 43.3 \\
\hline - mie & 11 & 18.3 \\
\hline \multicolumn{3}{|l|}{ 12. Tanggapan keluarga } \\
\hline - biasa saja & 32 & 53.3 \\
\hline - cuek & 1 & 1.7 \\
\hline - lebih perhatian & 26 & 43.3 \\
\hline - tidak tahu & 1 & 1.7 \\
\hline
\end{tabular}


Sebesar 43.3\% contoh menjawab dilarang makan nenas, $18.3 \%$ dilarang makan mie dan 6.7\% dilarang makan ikan ketika sedang menstruasi. Sebagian besar contoh tidak mengetahui mengapa makanan-makanan tersebut dilarang dikonsumsi, contoh hanya dilarang oleh orang tua tanpa penjelasan lebih lanjut (Tabel 7). Agustini (2007) mengungkapkan bahwa upaya untuk mengurangi PMS yaitu menghindari makanan dengan kadar garam tinggi, makanan manis, kafein, alkohol, makanan siap saji dan stres yang berkepanjangan. Selain itu, dianjurkan selalu melakukan olahraga rutin karena mampu meningkatkan produksi endorphin otak yang dapat menurunkan stres secara tidak langsung dan tidur minimal 8 jam/hari.

Tanggapan keluarga yang dirasakan oleh contoh ketika pertama kali mendapat menstruasi adalah biasa saja (53.3\%), lebih perhatian (43.3\%), cuek dan tidak tahu (1.7\%). Tanggapan biasa saja diduga lebih karena contoh sudah diberitahukan terlebih dahulu apa yang harus dilakukan ketika mendapat menstruasi, sedangkan untuk keluarga yang lebih perhatian disebabkan karena contoh belum mengetahui apapun sehingga harus lebih diperhatikan.

\section{Usia Menarche Ibu}

Sebesar $46.7 \%$ contoh yang sudah menstruasi dan $56.7 \%$ belum menstruasi menjawab bahwa usia menarche ibu yaitu 13-14 tahun. Hasil analisis uji beda menunjukkan tidak terdapat perbedaan antara usia menarche ibu pada kedua contoh $(p>0.05)$ (Tabel 7). Variasi umur rata-rata saat menarche merupakan interaksi dari perbedaan genetik dan lingkungan. Perbedaan umur menarche antara kelompok pedesaan dan perkotaan atau remaja putri kaya dan miskin di daerah tertentu, terutama karena perbedaan status sosial ekonomi yang berkaitan dengan kesehatan (WHO, 1995).

Pada beberapa situasi, perbedaan sosial atau ekonomi mencerminkan perbedaan etnik atau genetik. Menurunnya umur rata-rata saat menarche terlihat pada beberapa populasi dan perubahan sekular menandakan adanya perbaikan faktor-faktor yang berhubungan dengan kesehatan sehingga memungkinkan terjadinya kematangan (maturation) yang lebih cepat pada saat remaja. Sebagai contoh, di Norwegia rata-rata umur menarche menurun dari 15.6 tahun pada wanita yang dilahirkan tahun 1860 menjadi 13.3 tahun pada wanita yang dilahirkan setelah tahun 1940. Pada penelitian inipun terjadi penurunan umur menarche yaitu ibu mendapatkan menstruasi pada umur 13-14 tahun (umur ibu antara 35-45 tahun) dan rata- rata anaknya mendapatkan menstruasi pada umur 10-11 tahun yang dilahirkan pada tahun 1995-1996 (WHO, 1995).

Tabel 7. Sebaran Contoh berdasarkan Usia Menarche Ibu

\begin{tabular}{lcccc}
\hline \multirow{2}{*}{$\begin{array}{c}\text { Usia Menarche } \\
\text { lbu }\end{array}$} & \multicolumn{2}{c}{ Menstruasi } & \multicolumn{2}{c}{$\begin{array}{c}\text { Belum } \\
\text { Menstruasi }\end{array}$} \\
\cline { 2 - 5 } & $\mathbf{n}$ & $\%$ & $\mathbf{n}$ & $\%$ \\
\hline 9-10 tahun & 1 & 1.7 & 1 & 1.7 \\
11-12 tahun & 16 & 26.6 & 8 & 13.3 \\
13-14 tahun & 28 & 46.7 & 34 & 56.7 \\
15-16 tahun & 10 & 16.7 & 13 & 21.6 \\
17-18 tahun & 5 & 8.3 & 4 & 6.7 \\
\hline
\end{tabular}

Hasil analisis korelasi Spearman menunjukkan tidak terdapat hubungan nyata antara usia menarche ibu dengan usia menarche contoh ( $r=0.176 ; p>0.05)$. Ini menunjukkan bahwa usia menarche ibu tidak berhubungan dengan usia menarche anak. Hal ini bertentangan dengan yang diungkapkan Hanafiah (1987) yaitu usia menarche dipengaruhi oleh faktor keturunan, keadaan gizi (konsumsi dan status gizi) dan kesehatan umum. Seratus tahun yang lalu, rata-rata usia menarche adalah 15-19 tahun. Menurunnya usia menarche disebabkan oleh keadaan gizi dan kesehatan umum yang membaik serta berkurangnya penyakit menahun.

\section{Pola Konsumsi Pangan}

\section{Makanan Pantangan}

Makanan pantangan adalah makanan yang dilarang dimakan baik karena kondisi kesehatan maupun karena tabu/dilarang orang tua. Makanan pantangan ditanyakan dalam dua kondisi yaitu saat menstruasi dan saat sehat. Makanan pantangan contoh yang sudah menstruasi ketika kondisi sehat adalah chiki $10.0 \%$, es $6.7 \%$, coklat dan mie masing-masing $3.3 \%$. Alasannya karena batuk, amandel, sakit gigi dan takut gemuk.

Pada saat menstruasi makanan pantangannya adalah nenas $43.3 \%$, mie $20.0 \%$, ikan $6.7 \%$, makanan pedas $5 \%$ dan es $3.3 \%$. Alasannya adalah alergi, takut keputihan, sakit perut, mual, dan sebagian besar menjawab dilarang orang tua khususnya ibu. Contoh mampu menjawab sebatas dilarang ibunya tanpa ada penjelasan lebih jauh mengapa makananmakanan tersebut dilarang dimakan ketika menstruasi. Makanan pantangan contoh yang belum menstruasi pada saat kondisi sehat yaitu es $15 \%$, chiki $11.7 \%$, nenas $8.3 \%$, dan permen 5.0\%. Alasannya adalah batuk, amandel, takut keputihan, dan sakit gigi. 


\section{Konsumsi Pangan}

\section{J umlah dan J enis Pangan}

Konsumsi pangan meliputi informasi mengenai jenis pangan dan jumlah pangan yang dimakan seseorang atau kelompok orang (sekeluarga atau rumah tangga) pada waktu tertentu. Hal ini menunjukkan bahwa konsumsi pangan dapat ditinjau dari aspek jenis dan jumlah pangan yang dikonsumsi (Hardinsyah \& Martianto, 1988).

Total seluruh energi, protein, Fe, vitamin A dan vitamin C berasal dari makanan pokok, protein hewani, protein nabati, sayuran, buah, jajanan dan minuman. Total energi dan vitamin A contoh yang sudah menstruasi lebih tinggi dibandingkan contoh belum menstruasi yaitu 1833 kkal dan 467.9 RE. Total protein, Fe dan vitamin $C$ contoh yang sudah menstruasi lebih rendah dibandingkan contoh belum menstruasi yaitu $46.1 \mathrm{~g}, 14.3 \mathrm{mg}$ dan $51.0 \mathrm{mg}$ (Tabel 8).

Hasil analisis uji beda untuk total konsumsi energi dan zat gizi lainnya (protein, Fe, vitamin A dan vitamin C) menunjukkan tidak berbeda nyata antara contoh yang sudah menstruasi dengan contoh belum menstruasi $(P>0.05)$.

\section{Konsumsi dan Tingkat Kecukupan Zat Gizi}

Rata-rata konsumsi energi contoh yang sudah menstruasi adalah 1933 kkal dan ratarata konsumsi protein adalah $49.1 \mathrm{~g}$. Tingkat kecukupan energi contoh termasuk dalam kategori normal sedangkan tingkat kecukupan protein termasuk kategori defisit tingkat ringan. Rendahnya tingkat kecukupan protein disebabkan kurangnya jumlah protein yang dikonsumsi yaitu sebanyak 6.2 g. Rata-rata konsumsi zat besi adalah $15.1 \mathrm{mg}$, vitamin A 490.5 RE, dan vitamin C 55.2 mg. Tingkat kecukupan vitamin A termasuk dalam kategori cukup. Tingkat kecukupan vitamin C berlebih. Kelebihan vitamin dan mineral sampai $20 \%$ masih dapat ditolerir asal tidak berlangsung dalam waktu yang lama. Tingkat kecukupan Fe termasuk dalam kategori kurang. Hal ini disebabkan kurangnya contoh mengonsumsi pangan sumber Fe.

Rata-rata konsumsi energi contoh yang belum menstruasi adalah 1934 kkal dan ratarata konsumsi protein contoh adalah $53.7 \mathrm{~g}$ (Tabel 10). Tingkat kecukupan energi dan protein contoh termasuk dalam kategori kelebihan sebanyak 652 kkal dan $10.7 \mathrm{~g}$. Rata-rata konsumsi zat besi adalah $17.7 \mathrm{mg}$, vitamin A 449.8 RE dan vitamin C $71.2 \mathrm{mg}$. Tingkat kecukupan Fe termasuk dalam kategori cukup. Tingkat kecukupan vitamin C termasuk berlebih.

Tabel 8. Rata-rata Konsumsi Pangan, Energi dan Zat Gizi Contoh Menstruasi

\begin{tabular}{lccccc}
\hline \multirow{2}{*}{ Jenis Pangan } & \multicolumn{5}{c}{ Rata-rata konsumsi } \\
\cline { 2 - 6 } & $\begin{array}{c}\text { Energi } \\
\text { (kkal) }\end{array}$ & $\begin{array}{c}\text { Protein } \\
(\mathbf{g})\end{array}$ & $\begin{array}{c}\text { Fe } \\
(\mathbf{m g})\end{array}$ & $\begin{array}{c}\text { Vit. A } \\
\text { (RE) }\end{array}$ & $\begin{array}{c}\text { Vit. C } \\
(\mathbf{m g})\end{array}$ \\
\hline I. Makanan Pokok & 975 & 14.3 & 4.7 & 0.4 & 1.6 \\
II. Pangan Hewani & 261 & 18.1 & 3.4 & 97.6 & 0.7 \\
III. Pangan Nabati & 39 & 2.4 & 1.0 & 16.5 & 0.0 \\
IV. Sayuran & 17 & 0.9 & 0.4 & 282.8 & 19.3 \\
V. Buah-buahan & 30 & 0.2 & 0.7 & 6.0 & 14.4 \\
VI. Jajanan & 234 & 5.3 & 2.7 & 30.2 & 8.3 \\
VII. Minuman & 277 & 4.9 & 1.4 & 34.4 & 6.8 \\
\hline \multicolumn{1}{c}{ Total } & 1833 & 46.1 & 14.3 & 467.9 & 51.0 \\
\hline
\end{tabular}

Tabel 9. Rata-rata Konsumsi Pangan, Energi dan Zat Gizi Contoh Belum Menstruasi

\begin{tabular}{lccccc}
\hline \multirow{2}{*}{ Jenis Pangan } & \multicolumn{5}{c}{ Rata-rata konsumsi } \\
\cline { 2 - 6 } & $\begin{array}{r}\text { Energi } \\
\text { (kkal) }\end{array}$ & $\begin{array}{c}\text { Protein } \\
(\mathbf{g})\end{array}$ & $\begin{array}{c}\text { Fe } \\
\text { (mg) }\end{array}$ & $\begin{array}{c}\text { Vit. A } \\
\text { (RE) }\end{array}$ & $\begin{array}{c}\text { Vit. C } \\
\text { (mg) }\end{array}$ \\
\hline I. Makanan Pokok & 899 & 12.9 & 4.6 & 0.3 & 3.8 \\
II. Pangan Hewani & 285 & 21.9 & 3.2 & 92.8 & 0.6 \\
III. Pangan Nabati & 50 & 3.3 & 1.4 & 0.2 & 0.0 \\
IV. Sayuran & 18 & 1.0 & 0.5 & 252.2 & 16.7 \\
V. Buah-buahan & 33 & 0.5 & 0.4 & 26.5 & 23.3 \\
VI. Jajanan & 311 & 7.4 & 4.2 & 16.6 & 12.4 \\
VII. Minuman & 199 & 4.9 & 0.3 & 39.2 & 12.9 \\
\hline Total & 1795 & 51.9 & 14.6 & 428.1 & 69.7 \\
\hline
\end{tabular}


Tabel 11. Rata-rata Konsumsi, Kecukupan dan Tingkat Kecukupan Energi dan Zat Gizi Contoh yang Sudah Menstrusi dan Belum Menstruasi

\begin{tabular}{lrrrrrr}
\hline \multirow{2}{*}{ Zat Gizi } & \multicolumn{3}{c}{ Sudah Menstruasi } & \multicolumn{3}{c}{ Belum Menstruasi } \\
\cline { 2 - 7 } & Konsumsi & AKG contoh & TKG (\%) & Konsumsi & AKG contoh & TKG (\%) \\
\hline Energi (kkal) & 1933 & 2064 & 93.7 & 1934 & 1282 & 150.9 \\
Protein (g) & 49.1 & 55.3 & 88.8 & 53.7 & 43.0 & 124.9 \\
Zat Besi (mg) & 15.1 & 20 & 75.5 & 17.7 & 20 & 88.5 \\
Vitamin A (RE) & 490.5 & 600 & 81.7 & 449.8 & 600 & 75.0 \\
Vitamin C (mg) & 55.2 & 50 & 110.4 & 71.2 & 50 & 142.4 \\
\hline
\end{tabular}

Hasil analisis korelasi Spearman menunjukkan tidak terdapat hubungan nyata antara konsumsi pangan dengan usia menarche. Faktor lain yang diduga berkaitan dengan usia menarche dan tidak dianalisis oleh peneliti adalah proporsi lemak tubuh. Cadangan lemak dalam tubuh diperoleh apabila konsumsi karbohidrat, lemak dan protein berlebih. Menurut Riyadi (2003) perubahan kandungan lemak tubuh memberikan dugaan perubahan tidak langsung dalam keseimbangan energi. Proporsi lemak tubuh seseorang tidak hanya dilihat dari ukuran tubuh seseorang (kurus/gemuk) namun dapat diketahui melalui pengukuran antropometri menggunakan skinfold caliper.

\section{Status Gizi}

Sebagian besar contoh yaitu $86.7 \%$ yang sudah menstruasi dan $68.3 \%$ belum menstruasi berada pada kategori status gizi normal, namun sebanyak $25.0 \%$ contoh belum menstruasi termasuk dalam kategori kurus (Tabel 11). Hal ini diduga merupakan salah satu faktor yang mempengaruhi contoh belum mendapatkan menstruasi selain faktor-faktor penyebab lainnya.

Riyadi (2003) menyatakan bahwa remaja putri yang bergizi baik mempunyai kecepatan pertumbuhan yang lebih tinggi pada masa sebelum pubertas (prapubertas) dibandingkan dengan remaja yang kurang gizi. Menstruasi yang dimulai antara umur 10 dan 16 tahun dipengaruhi oleh beberapa faktor, termasuk di dalamnya kesehatan wanita, konsumsi gizi dan status gizi. Remaja kurang gizi ini tumbuh lebih lambat untuk waktu yang lebih lama, karena itu menarche (umur pertama kali mendapat menstruasi) juga tertunda.

Berdasarkan uji beda, terdapat perbedaan antara contoh yang sudah menstruasi dengan belum menstruasi $(p<0.05)$. Status gizi (IMT/U) contoh yang sudah menstruasi lebih banyak pada kategori normal sedangkan status gizi belum menstruasi pada kategori normal dan kurus.
Tabel 11. Sebaran Contoh berdasarkan Klasifikasi Status Gizi

\begin{tabular}{lcccc}
\hline \multirow{2}{*}{ Klasifikasi } & \multicolumn{2}{c}{ Menstruasi } & \multicolumn{2}{c}{$\begin{array}{c}\text { Belum } \\
\text { menstruasi }\end{array}$} \\
\cline { 2 - 5 } & $\mathbf{n}$ & $\%$ & $\mathbf{n}$ & $\%$ \\
\hline Kurus & 2 & 3.3 & 15 & 25.0 \\
Normal & 52 & 86.7 & 41 & 68.3 \\
Gemuk & 6 & 10.0 & 4 & 6.7 \\
\hline
\end{tabular}

Hasil analisis korelasi spearman menunjukkan status gizi mempunyai hubungan nyata yang negatif dengan usia menarche, artinya adalah semakin baik status gizi contoh maka semakin cepat usia menarche $(r=-0.062$; $p<0.05$ ). Hal ini sesuai dengan teori yang diungkapkan oleh Riyadi (2003) bahwa remaja putri yang bergizi baik mempunyai kecepatan pertumbuhan lebih tinggi pada masa sebelum pubertas (prapubertas) dibandingkan remaja yang kurang gizi. Menurunnya usia menarche disebabkan oleh keadaan gizi dan kesehatan umum yang membaik dan berkurangnya penyakit menahun (Hanafiah, 1987).

\section{KESIMPULAN}

Rata-rata konsumsi energi contoh yang sudah menstruasi adalah 1933 kkal dan ratarata konsumsi protein adalah $49.1 \mathrm{~g}$. Rata-rata konsumsi zat besi adalah $15.1 \mathrm{mg}$, vitamin $\mathrm{A}$ 490.5 RE, dan vitamin C $55.2 \mathrm{mg}$.

Rata-rata konsumsi energi contoh yang belum menstruasi adalah 1934 kkal dan ratarata konsumsi proteinnya $53.7 \mathrm{~g}$. Rata-rata konsumsi zat besi ada- lah $17.7 \mathrm{mg}$, vitamin A 449.8 RE dan vitamin C $71.2 \mathrm{mg}$.

Konsumsi pangan sumber energi, protein, zat besi, vitamin $\mathrm{A}$, dan vitamin $\mathrm{C}$ tidak berbeda antara contoh yang sudah menstruasi dengan belum menstruasi ( $p>0.05)$. Hasil analisis korelasi Spearman me- nunjukkan tidak terdapat hubungan nyata an- tara konsumsi pangan dengan usia menarche $(p>0.05)$. Faktor lain yang diduga berhubungan 
dengan usia menarche dan tidak dianalisis oleh peneliti adalah proporsi lemak tubuh.

Sebagian besar contoh yang sudah menstruasi $(86.7 \%)$ dan $68.3 \%$ yang belum menstruasi berada pada kategori status gizi normal, namun sebanyak $25.0 \%$ contoh belum menstruasi termasuk dalam kategori kurus. Berdasarkan uji beda, terdapat perbedaan status gizi antara contoh yang sudah menstruasi dengan belum menstruasi $(p<0.05)$. Berdasarkan uji korelasi Spearman, status gizi menunjukkan hubungan nyata yang negatif dengan usia menarche $(r=-0.062 ; p<0.05)$ artinya semakin baik status gizi contoh maka semakin awal usia menarche.

\section{DAFTAR PUSTAKA}

Agustini S. 2007. Pre menstruasl syndrome. http: //niex-klaten.blogspot.com. [22 Januari 2008].

Affandi B \& Danukusumo D. 1990. Gangguan Haid pada Remaja dan Dewasa. Balai Penerbit FKUI, Jakarta.

Fatimah E. 2006. Psikologi Perkembangan (Perkembangan Peserta Didik). Pustaka Setia, Bandung.

Hanafiah MJ. 1987. Haid dan Siklusnya. Dalam Wiknjosastro $\mathrm{H}$ (Ed.), Ilmu Kandungan. Bina Pustaka Sarwono Prawirohardjo, Jakarta.

Hardinsyah \& D Martianto. 1988. Menaksir Kecukupan Energi dan Protein serta Mutu Gizi Konsumsi Pangan. Wirasari, Jakarta.

Hurlock EB. 1980. Psikologi Perkembangan: Suatu pendekatan sepanjang rentang ke- hidupan. (Istiwidayanti \& Soedjarwo, Penerjemah). Erlangga, Jakarta.

Khaerunnisa. 2005. Hubungan kadar hemoglobin dengan skor keluhan menstruasi pada mahasiswa putri TPB IPB Tahun 2003/ 2004. Skripsi Sarjana Program Studi Gizi Masyarakat dan Sumberdaya Keluarga, Fakultas Pertanian, IPB, Bogor.

Papalia DE. \& Olds SW. 1979. A Child's World Infancy Through Adolescence. ( $2^{\text {nd }}$ ed.). New York: McGraw-Hill Book Company.

Ratsmawan H. 2007. Akibat fluktuasi hormon menyebabkan mudah marah hingga jerawatan. http://seksfile.wordpress.com [22 Januari 2008].

Riyadi H. 2003. Metode Penilaian Status Gizi secara Antropometri. Diktat Mata Kuliah Jurusan Gizi Masyarakat dan Sumberdaya Keluarga, Fakultas Pertanian, IPB, Bogor.

Simanjuntak P. 1987. Gangguan Haid dan Siklusnya. Dalam Wiknjosastro H (Ed.), Ilmu Kandungan. Bina Pustaka Sarwono Prawirohardjo, Jakarta.

Suhardjo. 1996. Berbagai Cara Pendidikan Gizi. Bumi Aksara bekerjasama dengan Pusat Antar Universitas Pangan dan Gizi, IPB, Jakarta.

Utami NH. 2003. Hubungan gizi dengan keluhan menstruasi pada remaja. Skripsi Sarjana Program Studi Gizi Masyarakat dan Sumberdaya Keluarga, Fakultas Pertanian, IPB, Bogor.

WHO. 1995. Physical Status: The Use and Interpretation of Anthropometry: report of a WHO expert committe. Geneva. 